\title{
Interaction of Hydroxyethylidene bisphosphonate (HEBP) with other endodontic irrigants on tissue dissolving capacity and antimicrobial effect
}

\author{
Ranah Kim, Yoon Gun Kim, Mi-Yeon Kim, Byung Chul Song, Sun-ho Kim, Jeong-hee Kim* \\ Department of Conservative Dentistry, Veterans Health Service Medical Center, Seoul, Republic of Korea
}

\begin{abstract}
Purpose: The purpose of this study was to evaluate tissue dissolving capacity, antimicrobial effect of Hydroxyethylidene bisphosphonate (HEBP) interacting with sodium hypochlorite ( $\mathrm{NaOCl}$ ), Ethylenediaminetetraacetic acid (EDTA) as conventional endodontic irrigants and to determine tissue dissolving efficacy depended on temperature. Materials and Methods: A total of 80 bovine muscles were randomly distributed into 8 groups $(n=10)$. After their initial weights determined on a precision scale, the specimens in each group were immersed in the solutions for 5, 10 and $15 \mathrm{~min}$ and reweighted at each time period. Agar diffusion test inoculated with Enterococcus faecalis was performed for antimicrobial effect of each endodontic irrigants. Results: The ability to dissolve organic matter was greater in $\mathrm{NaOCl}$ group following $\mathrm{NaOCl}$ and $\mathrm{HEBP}$ mixture. Heated $\mathrm{NaOCl}\left(40^{\circ} \mathrm{C}\right)$ and $\mathrm{NaOCl} / \mathrm{HEBP}$ mixture was greater tissue dissolving efficacy than room temperature $\left(25^{\circ} \mathrm{C}\right)$. Antimicrobial effect was greater and significant in the following order EDTA > EDTA $+1 \% \mathrm{NaOCl}>1 \% \mathrm{NaOCl} \geq 1 \% \mathrm{NaOCl}+\mathrm{HEBP}$. Conclusion: HEBP as soft chelating agent does not disturb antimicrobial effect and less affected tissue dissolving efficacy as inherent properties of $\mathrm{NaOCl}$. In the heated $\mathrm{NaOCl} / \mathrm{HEBP}$ mixture analyzed, it dissolved more the organic matter than room temperature. (J Dent Rehabil Appl Sci 2017;33(2):106-13)
\end{abstract}

Key words: HEBP (Hydroxyethylidene bisphosphonate); endodontic irrigants; soft chelating agent; tissue dissolving capacity; antimicrobial effect

\section{서론}

근관 치료 영역에서 세척과 성형의 최종적인 목표는 근 관 내 미생물과 괴사된 조직의 잔사를 최소한으로 줄이 는 것이다. 근관 치료 시 기계적인 기구 조작만 시행한 경 우, 근관계의 isthmus나 측방관, fin 등 기구가 도달하지 못하는 해부학적인 영역이 $40-50 \%$ 정도에 달한다. ${ }^{1}$ 따 라서 적절한 근관 치료를 위해서는 기계적인 세정 뿐만 아니라 근관 세정제를 이용한 화학적인 세정이 동반되어 야 한다.

Sodium hypochlorite $(\mathrm{NaOCl})$ 는 근관 치료에서 가

*Correspondence to: Jeong-hee Kim

Department of Conservative Dentistry, Veterans Health Service Medical Center, 53, Jinhwangdo-ro 61-gil, Gangdong-gu, Seoul, 05368, Republic of Korea Tel: +82-2-2225-1925, Fax: +82-2-2225-3929, E-mail: endo95@naver.com Received: March 16, 2017/Last Revision: May 8, 2017/Accepted: May 16, 2017
장 흔하게 사용되는 근관 세정제로서 항 세균 효과와 유 기성분을 용해하는 독특한 성질을 갖는다. ${ }^{2}$ 근관계에서 $\mathrm{NaOCl}$ 세정제의 효과를 개선시키기 위한 방법으로 높 은 농도를 사용하거나 가열하여 사용하는 방법이 있다. 낮은 농도를 갖는 $\mathrm{NaOCl}$ 용액의 온도를 증가시키면 즉 각적인 조직 용해 능력을 높이며, 상아질 잔사로부터 유 기질 잔사를 더 효과적으로 제거할 수 있다. Sirtes 등에 의하면 온도가 $25^{\circ} \mathrm{C}$ 오르면 $\mathrm{NaOCl}$ 의 효과는 100 배 증 가했다. 또한 $45^{\circ} \mathrm{C}$ 에서 $1 \% \mathrm{NaOCl}$ 을 사용하여 인간 치 수세포를 용해하는 능력은 $20^{\circ} \mathrm{C}$ 에서 $5.25 \%$ 용액을 사 용한 것과 같다는 연구 결과를 발표하였다. ${ }^{3}$ 
그러나 $\mathrm{NaOCl}$ 은 무기 성분으로 구성된 도말층을 제거 할 수 없다는 한계를 갖는다. 이러한 단점을 극복하기 위 해서, Etylenediaminetetraacetic acid (EDTA)와 같은 킬 레이팅 제재를 이용하여 상아질 벽에 도말층을 제거하고 기구 조작 동안의 경조직 잔사의 축적을 감소시킨다. ${ }^{4}$ 그 러나 EDTA는 $\mathrm{NaOCl}$ 과 반응하여 $\mathrm{NaOCl}$ 의 자유 염소기 가 소멸되어 특유의 조직용해 능력과 항균 효과를 저해시 킨다고 밝혀졌다. ${ }^{5}$ 따라서 근관 치료 시 $\mathrm{NaOCl}$ 과 EDTA 는 혼합하여 사용해서는 안되며, $\mathrm{NaOCl}$ 과 EDTA를 각 각 교대로 30 - 60초 적용하여 사용해야 한다.

이러한 이유로 1-hydroxyethlidene-1,1,-bisphosphonate (HEBP)와 같은 soft chelating agent 들이 EDTA 의 대체제로 소개되고 있다. HEBP는 EDTA 혹은 citric acid와 유사하게 도말층을 제거하는 능력을 가지며, $\mathrm{NaOCl}$ 과 혼합하여 사용해도 $\mathrm{HEBP}$ 고유의 킬레이팅 능력과, 도말층을 제거하는 성질을 저해하지 않고, 자유 염소기의 활성에 영향을 받는 $\mathrm{NaOCl}$ 의 항 세균 효과와 유기성분을 용해하는 성질에도 영향을 미치지 않는다고 알려졌다. ${ }^{6}$

이번 연구는 근관 세정제로서 $\mathrm{HEBP}$ 를 $\mathrm{NaOCl}, \mathrm{EDTA}$ 와 비교 시에 조직용해 능력, 항균효과에 대해 알아보고 각각의 세정제의 상호작용에 대해 평가한다. 또한, 온도 에 따른 조직 용해 능력의 변화에 대해 알아보았다.

\section{연구 재료 및 방법}

\section{1. 조직 용해 능력}

치아의 연조직을 대신하여 소의 근육을 $2 \times 2 \times 2 \mathrm{~mm}$ 의 크기로 stainless-steel blade를 이용하여 절단하여 표 면적과 초기 무게가 같은 80 개의 표본을 준비하였다. 표 본은 임의로 8 개의 그룹 $(\mathrm{n}=10)$ 으로 나누어, blot dry 한 후 초기 무게를 측정하기 위해 전자저울을 이용하였다. 각 그룹은 다음과 같은 근관 세정제에 넣었다(Table 1).

조직 표본을 튜브에 담그기 직전에 그룹 $6,7,8$ 의 용 액은 바로 혼합하였다. 그룹 $1,2,3,4,8$ 은 $25^{\circ} \mathrm{C}$ 실온에 서 보관 혹은 혼합되었다. 그룹 5,8 은 혼합 후 $40^{\circ} \mathrm{C}$ 설정 된 항온수조에 보관하였다. 각각의 그룹에 해당되는 용 액 $10 \mathrm{~mL}$ 를 튜브에 채운 후, 조직 표본을 넣었다. 5 분 후, 표본은 즉시 증류수로 옮겨서 30초 동안 용액을 제거하 여 blot dry를 시행 후 무게를 재 측정 하였다. 이러한 과 정을 5 분마다 반복하여, 용액에 침전시킨 5 분, 10 분, 15
Table 1. Solutions for the experiment of tissue dissolving capacity

\begin{tabular}{cl}
\hline Groups & \multicolumn{1}{c}{ Solutions } \\
\hline 1 & Normal saline (control group) \\
2 & $17 \% \mathrm{EDTA}$ \\
3 & $18 \% \mathrm{HEBP}$ \\
4 & $2.25 \% \mathrm{NaOCl}\left(25^{\circ} \mathrm{C}\right)$ \\
5 & $2.25 \% \mathrm{NaOCl}\left(40^{\circ} \mathrm{C}\right)$ \\
& $1: 15.5 \% \mathrm{NaOCl}+17 \% \mathrm{EDTA} \rightarrow$ finally, \\
6 & $2.25 \% \mathrm{NaOCl} / 8.5 \% \mathrm{EDTA}$ mixture $\left(25^{\circ} \mathrm{C}\right)$ \\
& $1: 15.5 \% \mathrm{NaOCl}+18 \% \mathrm{HEBP} \rightarrow$ finally, \\
& $2.25 \% \mathrm{NaOCl} / 9 \% \mathrm{HEBP}$ mixture $\left(25^{\circ} \mathrm{C}\right)$ \\
& $1: 15.5 \% \mathrm{NaOCl}+18 \% \mathrm{HEBP} \rightarrow$ finally, \\
& $2.25 \% \mathrm{NaOCl} / 9 \% \mathrm{HEBP}$ mixture $\left(40^{\circ} \mathrm{C}\right)$ \\
\hline
\end{tabular}

EDTA, etylenediaminetetraacetic acid; HEBP, hydroxyethylidene bisphosphonate; $\mathrm{NaOCl}$, sodium hypochlorite.

분 후의 측정값을 구했다.

조직 무게 변화율

$=\frac{\text { 수화된 조직의 무게 }- \text { 초기 조직의 무게 }}{\text { 초기 조직의 무게 }} \times 100$

\section{2. 항균효과}

Brain-heart infusion (BHI) agar를 이용한 8개의 Petri dish를 준비하였다. 한천배지는 제조사의 지시대로 혼합 하여, 이 plate는 실온에서 2일간 보관하였다. 동결 건조 된 Enterococcus faecalis (KCTC 5290, from dental plaque, human)을 활성화 시킨 후, E. faecalis를 BHI broth (Sigma-Aldrich, St Louis, USA)에 24시간 동안 배양하 고, 박테리아의 성장을 혼탁도의 변화로 확인하였다. 순 수하게 배양된 E. faecalis를 $\mathrm{BHI}$ broth에 접종한 후 한천 배지에 도말 하였다. 한천이 굳은 후에, $5 \mathrm{~mm}$ 직경으로 6 개의 동그란 와동을 형성하고, 준비된 와동에 각 용액 $10 \mu l$ 를 떨어뜨렸다. 준비된 용액은 6개의 그룹으로 나 누었다(Table 2).

위 한천배지를 $37^{\circ} \mathrm{C}$ 배양기(Fig 1)에 48시간 동안 보 관한 후, 가장 넓은 너비를 갖는 세균 성장 억제대(zones of microbial inhibition)를 반복해서 측정하여 기록한다. 

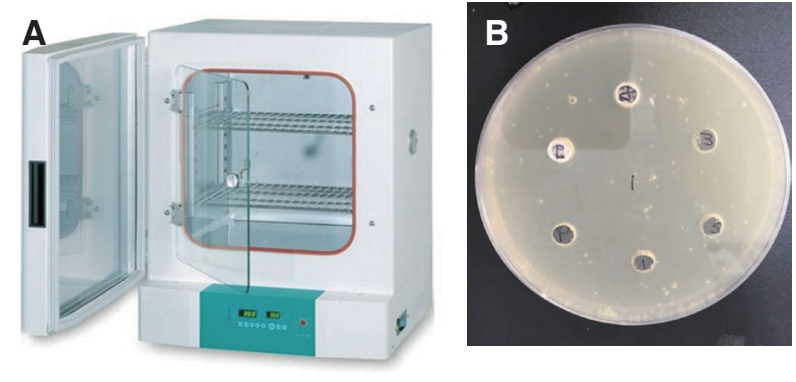

Fig. 1. (A) General Lan Incubator IB 05-G (60L, Jeio Tech, Inc., Seoul, Korea), (B) Model for Petri dish set up.

Table 2. Solutions for the experiments of antibacterial efficacy

\begin{tabular}{|c|c|}
\hline Group & Solution \\
\hline A & $1 \% \mathrm{NaOCl}$ \\
\hline $\mathrm{B}$ & 8.5\% EDTA \\
\hline $\mathrm{C}$ & $\begin{array}{l}1: 12 \% \mathrm{NaOCl}+17 \% \text { EDTA } \rightarrow \\
\text { finally, } 1 \% \mathrm{NaOCl} / 8.5 \% \text { EDTA mixture }\end{array}$ \\
\hline $\mathrm{D}$ & $9 \%$ HEBP \\
\hline $\mathrm{E}$ & $\begin{array}{l}1: 12 \% \mathrm{NaOCl}+18 \% \mathrm{HEBP} \rightarrow \\
\text { finally, } 1 \% \mathrm{NaOCl} / 9 \% \mathrm{HEBP}\end{array}$ \\
\hline $\mathrm{F}$ & Saline (control group) \\
\hline
\end{tabular}

$\mathrm{NaOCl}$, sodium hypochlorite; EDTA, etylenediaminetetraacetic acid; HEBP, hydroxyethylidene bisphosphonate.

\section{3. 통계}

무게 변화 측정의 경우 일원 변량 분석(ANOVA)을 사 용하였으며 Mann-Whitney test를 이용하여 사후 검정 하였다. 항균 효과의 실험은 일원변량분석(ANOVA)와 Kruskal-Wallis' test를 사용하였으며 Mann-Whitney test 를 이용하여 사후 검정하였다. 위의 분석은 모두 SPSS (statistics data editor version 20, IBM, Chicago, USA) 프로그램을 이용하였다.

\section{결과}

\section{1. 조직 용해 능력}

(1) 시간 경과에 따른 조직 용해 능력

초기 5 분 동안 모든 그룹에서 무게의 증가를 보인 다(Fig. 2, Table 3). 그러나, 5 - 10분 사이에 Group 4 와 Group 5에서 무게의 감소가 발생하며, Group 7과 Group 8은 $10-15$ 분 사이에 감소를 나타낸다. 반면 Group 1, 2, 6에서는 측정 시간 동안 유의미한 무게의 변

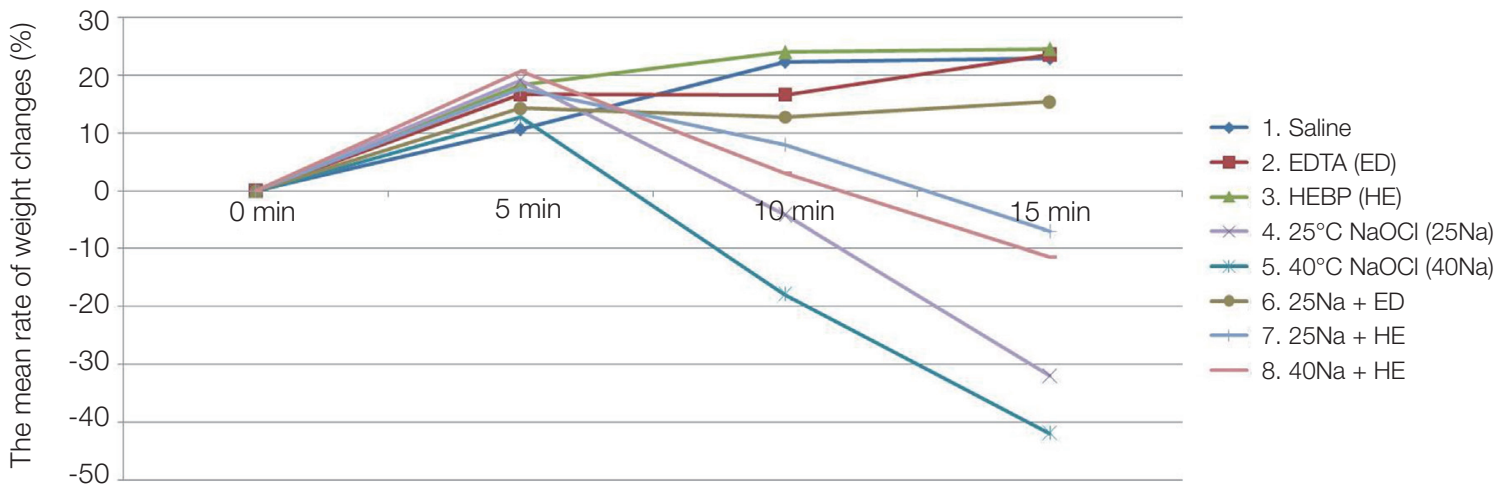

Fig. 2. The mean rate of weight changes (\%) after $5 \mathrm{~min}, 10 \mathrm{~min}$ and $15 \mathrm{~min}$ of submersion to the irrigation solutions. EDTA, etylenediaminetetraacetic acid; HEBP, hydroxyethylidene bisphosphonate; $\mathrm{NaOCl}$, sodium hypochlorite.

Table 3. Tissue dissolving efficacy depended on time

\begin{tabular}{lllll}
\hline & $0 \mathrm{~min}$ & $5 \mathrm{~min}$ & $10 \mathrm{~min}$ & $15 \mathrm{~min}$ \\
\hline Group 1 & $0.000 \%$ & $10.651 \%$ & $22.313 \%$ & $22.918 \%$ \\
Group 2 & $0.000 \%$ & $16.724 \%$ & $16.635 \%$ & $23.607 \%$ \\
Group 3 & $0.000 \%$ & $18.331 \%$ & $23.956 \%$ & $24.497 \%$ \\
Group 4 & $0.000 \%$ & $19.147 \%$ & $-4.103 \%$ & $-31.944 \%$ \\
Group 5 & $0.000 \%$ & $12.795 \%$ & $-17.825 \%$ & $-41.853 \%$ \\
Group 6 & $0.000 \%$ & $14.321 \%$ & $12.770 \%$ & $15.447 \%$ \\
Group 7 & $0.000 \%$ & $21.551 \%$ & $10.260 \%$ & $-5.860 \%$ \\
Group 8 & $0.000 \%$ & $20.635 \%$ & $3.034 \%$ & $-11.442 \%$ \\
\hline
\end{tabular}


화가 나타나지 않았다. Group 7은 Group 6에 비해 더 많은 무게의 소실을 관찰할 수 있었고, 15 분 후에 더 현 저하게 관찰되었다 $(P<0.05$, Fig. 3). Group 4와 비교 했을 때는, 10 분과 15 분 후 모두에서 $\mathrm{HEBP}$ 를 혼합한 Group 7에서 조직용해능력이 떨어졌다 $(P<0.05)$.

(2) 온도 증가에 따른 조직 용해 능력

가열된 $\mathrm{NaOCl}$ 용액 $\left(40^{\circ} \mathrm{C}\right)$ 은 더 높은 조직용해능력을 갖는다(Fig. 4). 시간이 지나면서 Group 5는 Group 4 보 다 더 큰 무게의 감소를 보이며, 15 분 후에는 유의한 차 이가 있었다 $(P<0.05)$. Group 8은 Group 7 보다 더 큰 무게의 감소를 보이나 두 그룹 사이에 유의한 차이는 나 타나지 않았다.

\section{2. 항균효과}

EDTA group에서 가장 넓은 미생물 억제대를 보였고, 다음으로 $1 \% \mathrm{NaOCl}$ group이 항균효과를 보였다(Table 4). HEBP 만 사용한 경우와 대조군(증류수)의 경우 미생 물 억제의 효과가 나타나지 않았다. $\mathrm{NaOCl} / \mathrm{EDTA}$ 혼 합용액은 EDTA만 사용한 경우와 비교 시 유의미한 감 소가 나타났다 $(P<0.05)$. 반면, $\mathrm{NaOCl} / \mathrm{HEBP}$ 혼합물 은 순수한 $\mathrm{NaOCl}$ 용액만 사용한 경우와 비교 시 미생물 억제대의 경우 유의한 차이가 나타나지 않았다. 이 혼합 물은 전통적인 $\mathrm{NaOCl}$ 용액의 항균효과를 저해하지 않 는다.

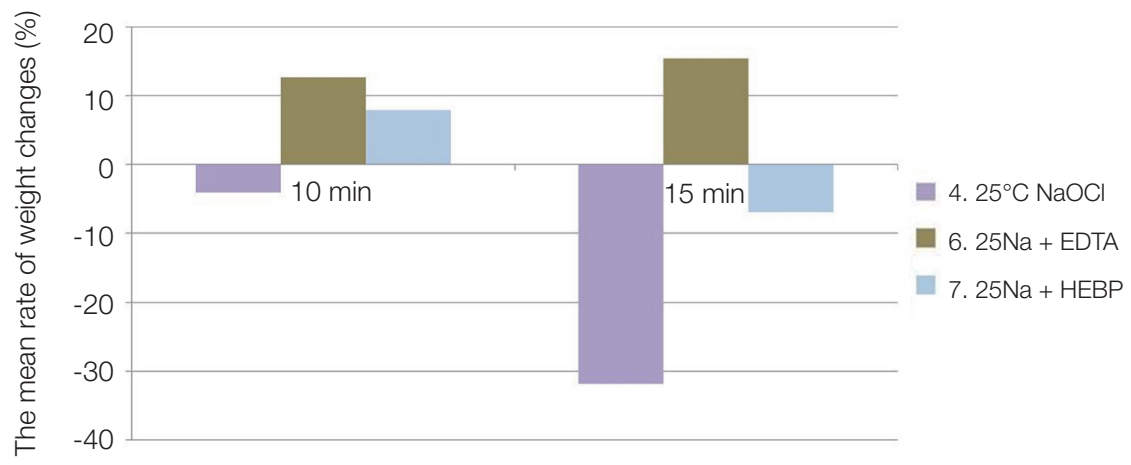

Fig. 3. The effect of HEBP. These graphs show comparisons of the mean rate of weight change (\%) of Group 4, 6 and 7 after $10 \mathrm{~min}$ and $15 \mathrm{~min}$ submersion to the irrigation solutions. Values are shown as the mean. $\mathrm{NaOCl}$, sodium hypochlorite; EDTA, etylenediaminetetraacetic acid; HEBP, hydroxyethylidene bisphosphonate.

A

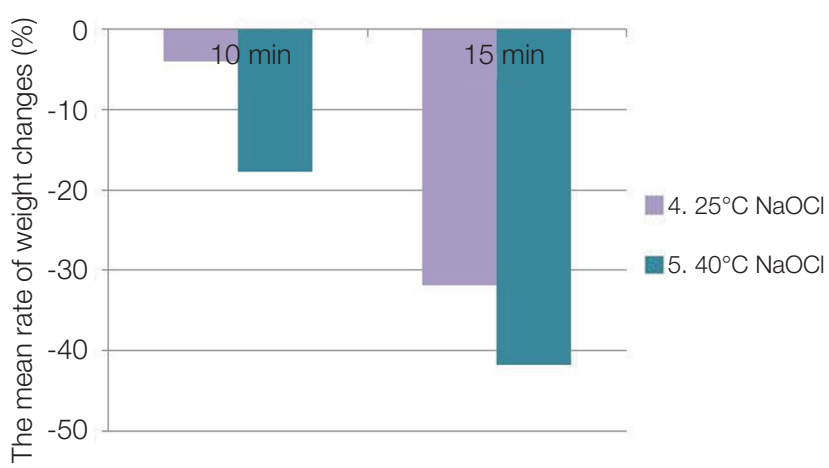

B

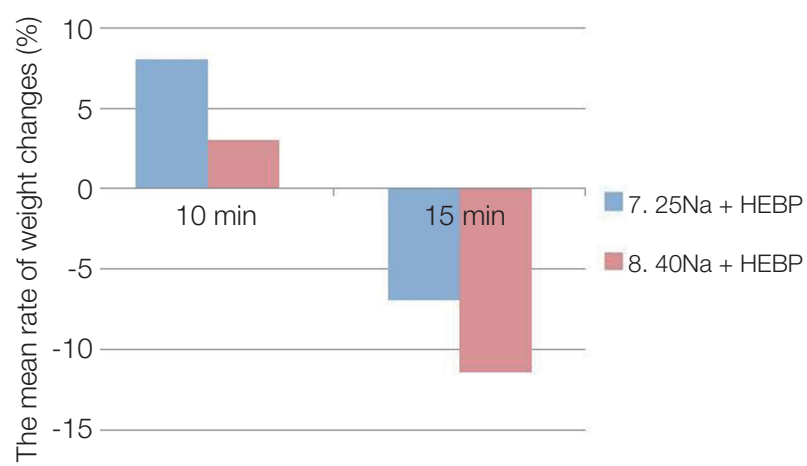

Fig. 4. The effect of temperature increase. These graphs show comparisons of the mean rate of weight change (\%) of $25^{\circ} \mathrm{C}$ and $40^{\circ} \mathrm{C}$ groups after $10 \mathrm{~min}$ and $15 \mathrm{~min}$ of submersion to $\mathrm{G} 4$ and G5 (A), G7 and G8 (B). Values are shown as the mean. $\mathrm{NaOCl}$, sodium hypochlorite; HEBP, hydroxyethylidene bisphosphonate. 
Table 4. Zones of inhibition ( $\mathrm{mm}$ ) against organisms (agar diffusion test)

\begin{tabular}{lcccccc}
\hline & $\begin{array}{c}\text { Group A } \\
\text { (NaOCl) }\end{array}$ & $\begin{array}{c}\text { Group B } \\
\text { (EDTA) }\end{array}$ & $\begin{array}{c}\text { Group C } \\
(\mathrm{NaOCl} / \mathrm{EDT})\end{array}$ & $\begin{array}{c}\text { Group D } \\
(\text { HEBP })\end{array}$ & $\begin{array}{c}\text { Group E } \\
(\mathrm{NaOCl} / \mathrm{HEBP})\end{array}$ & $\begin{array}{c}\text { Group F } \\
\text { (Saline) }\end{array}$ \\
\hline Mean & 7.675 & 15.938 & 11.338 & 0.000 & 7.313 & 0.000 \\
Standard deviation & 1.309 & 1.374 & 1.151 & 0.000 & 0.897 & 0.000 \\
\hline
\end{tabular}

$\mathrm{NaOCl}$, sodium hypochlorite; EDTA, etylenediaminetetraacetic acid; HEBP, hydroxyethylidene bisphosphonate.

\section{고찰}

이번 실험에서는 상아질 내 도말층을 제거하기 위한 근 관 세정제로서 soft cheating agent 인 1-hydroxyethlidene -1,1,-bisphosphonate (HEBP)를 사용하여 조직 용해 능 력과 항균작용에 대하여 평가하였다. $\mathrm{HEBP}$ 는 독성이 없어 골 질환 치료 시 일반적으로 사용되며, 가정 내에서 건강 보조제와 개인 생활용품으로도 사용된다. ${ }^{7} \mathrm{HEBP}$ 는 $\mathrm{NaOCl}$ 과 반응하지 않으며 $\mathrm{NaOCl}$ 과 혼합되어도 킬 레이트 능력이 유지되어 기구 조작하는 동안에도 문제 없이 사용할 수 있다. ${ }^{6} \mathrm{HEBP}$ 의 도말층에 대한 작용을 연구한 Kruvilla 등에 의하면 HEBP는 치근의 cervical 과 middle 부위에서 EDTA, maleic acid와 유사한 도말 층 제거 능력을 보이나, 치근단 부위에서는 EDTA와는 비슷하지만 maleic acid보다는 저하된 도말층 제거 효과 를 보인다. ${ }^{8}$ 하지만 soft chelating agent 임에도 불구하 고 근관 내로부터 용출된 칼슘 이온의 양은 약한 알칼리 성 환경에서 $\mathrm{EDTA}$ 와 비슷하다. ${ }^{9} \mathrm{HEBP}$ 로 처리한 치근 상아질은 다른 킬레이팅 제재와 비교 시에 가장 높은 미 세경도를 보인다. ${ }^{10}$ 이것은 HEBP로 처리한 경우 EDTA 로 처리한 상아질보다 상아세관 면적이 작고 관간 상아 질 면적은 더 넓어지기 때문이다. 또한 상아질 접착의 대 부분도 상아세관보다는 관간 상아질에 있는 교원질 기질 과의 미세 기계적 유지에 의해 얻어지므로 $\mathrm{HEBP}$ 를 처리 한 상아질 접착이 더 유리할 것이다. ${ }^{11}$

조직의 용해 능력을 비교한 실험에서, 초기 5 분 동안 모든 표본의 무게가 증가하는 것을 관찰할 수 있다. 이 것은 조직의 수화과정의 결과로 일어난다. $\mathrm{NaOCl}$ 만 사 용한 그룹에서 가장 빠르게 조직용해가 나타나며 이어 서 $\mathrm{NaOCl}$ 과 $\mathrm{HEBP}$ 를 혼합하여 사용한 그룹에서 다음 으로 큰 무게 변화의 폭이 나타났다. 이 것은 $\mathrm{HEBP}$ 를 단독으로 사용하였을 때는 조직용해능력을 갖지 못하지 만, $\mathrm{HEBP}$ 와 $\mathrm{NaOCl}$ 을 혼합하여 사용시에는 $\mathrm{NaOCl}$ 의 조직용해 능력에 영향을 미치지 않는다는 기존의 연구
결과와 어느 정도 일치하였다. ${ }^{6}$ 하지만 이번 실험에서는 $\mathrm{NaOCl}$ 단독으로 사용했을 때보다는 조직용해능력이 조 금 감소하는 효과가 나타났다. $\mathrm{NaOCl}$ 과 EDTA를 혼합 하여 사용한 그룹에서는 거의 무게변화가 나타나지 않았 다. Grawher 등의 실험에서 $\mathrm{EDTA}$ 는 $\mathrm{NaOCl}$ 용액 존재 하에서도 킬레이트 반응을 일으킬 수 있는 능력이 유지 되나 $\mathrm{NaOCl}$ 용액은 $\mathrm{EDTA}$ 의 존재 시 유효 염소 농도가 $0.5 \%$ 에서 $0.06 \%$ 로 현저히 감소되어 조직 용해능력이 감 소됨이 밝혀졌다. ${ }^{5}$

가열된 $\mathrm{NaOCl}\left(40^{\circ} \mathrm{C}\right)$ 를 사용시에 실온의 $\mathrm{NaOCl}\left(25^{\circ}\right.$ C)를 사용시 보다 더 큰 조직용해능력을 보였고, $\mathrm{NaOCl}$ 과 $\mathrm{HEBP}$ 를 혼합하여 사용한 경우에도 유의미하지는 않 지만 가열된 그룹에서 더 큰 조직용해능력이 나타났다. 소의 인대에서 추출한 교원질을 이용하여 실온 $\left(21^{\circ} \mathrm{C}\right)$ 과 체온 $\left(37^{\circ} \mathrm{C}\right)$ 에서 $2.6 \%$ 와 $5.2 \% \mathrm{NaOCl}$ 용액의 교원질 용 해 능력을 비교한 결과 $37^{\circ} \mathrm{C} 2.6 \% \mathrm{NaOCl}$ 용액은 $21^{\circ} \mathrm{C}$, $37^{\circ} \mathrm{C} 5.2 \% \mathrm{NaOCl}$ 용액과 동등한 조직용해 능력을 보였 다. ${ }^{12}$ 조직용해 능력 뿐만 아니라 $\mathrm{NaOCl}$ 의 항균 효과는 5 - 60 범위 내에서 온도가 $5^{\circ} \mathrm{C}$ 오를 때 두 배 증가한다 고 밝혀졌다. ${ }^{13}$

이번 실험에서는 E. faecalis에 대한 근관 세정제의 항균 효과를 관찰하였다. E. faecalis는 구강 내에서 가장 저항 성이 높은 세균종이며 종종 근관 내 재감염을 일으키기 도 한다. 따라서 근관 세정재 및 첩약제의 항균효과 및 감수성을 평가하는데 흔히 이용되는 세균종이다. ${ }^{14}$ 이 실 험에서는 EDTA group에서 가장 넓은 미생물 억제대 가 나타났다. Siqueira 등의 실험에 의하면 agar diffusion model을 이용한 연구에서 E. faecalis에 대한 항균작용 은 EDTA group이 $0.5 \% \mathrm{NaOCl}$ 보다는 뛰어나나 $2.5 \%$ $\mathrm{NaOCl}$ 보다 낮은 값을 나타냈다. ${ }^{14}$ 이번 실험에 의하면 EDTA의 항균 작용이 $1 \% \mathrm{NaOCl}$ 보다도 뛰어난 것으 로 추정된다. 하지만 임상적으로 감염된 상아질 내에서 EDTA의 항균효과는 미미하게 나타난다. 그 이유는 근 관계 내에서 $\mathrm{EDTA}$ 는 치아 경조직과 반응하여 비활성화 
되기 때문이다. ${ }^{15}$ 이번 실험에서 HEBP 단독적으로 사용 시에 항균효과가 나타나지 않았으며 이것은 기존의 연구 와도 일치한다. ${ }^{6} 1 \% \mathrm{NaOCl}$ 을 단독으로 사용한 그룹과 $\mathrm{NaOCl}$ 과 $\mathrm{HEBP}$ 의 혼합물의 미생물저해영역에는 유의 한 차이가 나타나지 않았다. 이것은 항균효과가 활성화 된 자유 염소기에만 영향을 받는데, $\mathrm{NaOCl}$ 과 $\mathrm{HEBP}$ 를 혼합한 경우에도 활성화된 자유 염소기가 안정적으로 유 지되기 때문으로 추정된다. 따라서 $\mathrm{NaOCl}$ 와 HEBP 혼 합물은 근관 치료 동안 혹은 최종 근관 세정제로서 사용 될 수 있다. ${ }^{6}$

이번 연구에서는 조직용해능력을 평가하기 위하여 소 의 근육 조직을 이용하였다. 이전의 다른 조직 용해 능력 을 평가하는 연구들에서도 소의 치수조직이나, 돼지의 구개 점막, 쥐의 dermal connective tissue 등이 사용되었 다. 인간 치수 조직과 다른 유형의 조직을 사용하는 이유 는 쉽게 표본을 표준화 시킬 수 있기 때문이다. 그러나 이 러한 조직들은 임상적으로 인간의 근관 내의 환경을 재 현하지 못한다는 한계가 있어 아쉽다. 조직 용해 능력은 세정제의 양, 실험 조직의 단면적, 교반 횟수 등 여러 가 지 요소들에 영향을 받는다. ${ }^{16}$ 따라서 이번 연구에서 표 본의 단면적을 균일하게 하기 위해 노력하였으며, 일정량 의 근관 세정제를 사용하기 위해 노력하였다

항균 효과를 평가하기 위해서 agar diffusion test를 사 용하였다. 그러나 상아질 기질 내에서 세정제의 항균효 과를 배양 방법을 사용하여 평가하는 것은 한계가 있다. 이 것은 박테리아가 검출된 곳이 치수강의 어느 부위인지 정확이 알 수 없으며, 근관벽 혹은 상아세관 내부에 잔존 하는 부착 biofilm 내에 잔존 박테리아를 확인할 수 없다. 최근에는 confocal microscopy를 사용하여 부착된 세포 의 방해 없이 상아세관 내부에 살아있는 박테리아를 확 인하고 정량화 하는 방법을 사용하기도 한다. ${ }^{17}$ 따라서 Biofilm을 확인하는 agar diffusion test 뿐만 아니라 상아 세관 내의 박테리아를 확인하는 Confocal laser scanning microscopy 실험이 추가적으로 필요할 것이다.

\section{결론}

이번 연구에서 Soft Chelating agent 인 HEBP는 $\mathrm{NaOCl}$ 의 항균 효과를 방해하지 않는다. HEBP와 $\mathrm{NaOCl}$ 의 혼합물은 기존의 킬레이팅 제재인 EDTA와 $\mathrm{NaOCl}$ 의 혼합물과 비교 시, $\mathrm{NaOCl}$ 의 조직 용해 능력에 미치는 영향이 작다. 하지만 $\mathrm{NaOCl}$ 단독으로만 사용했
을 때와 비교시에는 저하된 조직 용해 능력이 나타났다. 가열된 $\mathrm{NaOCl}, \mathrm{NaOCl}$ 과 $\mathrm{HEBP}$ 의 혼합재제는 실온과 비교 시에 효율적으로 조직을 용해할 수 있다. 따라서 근 관 치료 동안 $\mathrm{NaOCl}$ 과 동시에 도말층을 제거하는 근관 세정제로서 사용할 수 있다.

\section{ORCID}

Ranah Kim http://orcid.org/0000-0002-4718-8376

\section{References}

1. Peters OA, Laib A, Göhring TN, Barbakow F. Changes in root canal geometry after preparation assessed by high-resolution computed tomography. J Endod 2001;27:1-6.

2. Zehnder M, Kosicki D, Luder H, Sener B, Waltimo T. Tissue-dissolving capacity and antibacterial effect of buffered and unbuffered hypochlorite solutions. Oral Surg Oral Med Oral Pathol Oral Radiol Endod 2002;94:756-62.

3. Sirtes G, Waltimo T, Schaetzle M, Zehnder M. The effects of temperature on sodium hypochlorite short-term stability, pulp dissolution capacity, and antimicrobial efficacy. J Endod 2005;31:669-71.

4. Wang Z, Shen Y, Haapasalo M. Effect of smear layer against disinfection protocols on Enterococcus faecalis-infected dentin. J Endod 2013;39:1395400.

5. Grawehr M, Sener B, Waltimo T, Zehnder M. Interactions of ethylenediamine tetraacetic acid with sodium hypochlorite in aqueous solutions. Int Endod J 2003;36:411-7.

6. Zehnder M, Schmidlin P, Sener B, Waltimo T. Chelation in root canal therapy reconsidered. J Endod 2005;31:817-20.

7. Russell RG, Rogers MJ. Bisphosphonates: from the laboratory to the clinic and back again. Bone 1999; 25:97-106.

8. Kuruvilla A, Jaganath BM, Krishnegowda SC, Ramachandra PK, Johns DA, Abraham A. A comparative evaluation of smear layer removal by using edta, etidronic acid, and maleic acid as root canal irrigants: an in vitro scanning electron microscopic 
study. J Conserv Dent 2015;18:247-51.

9. Lottanti S, Gautschi H, Sener B, Zehnder M. Effects of ethylenediaminetetraacetic, etidronic and peracetic acid irrigation on human root dentine and the smear layer. Int Endod J 2009;42:335-43.

10. Dineshkumar MK, Vinothkumar TS, Arathi G, Shanthisree P, Kandaswamy D. Effect of ethylene diamine tetra-acetic acid, MTAD ${ }^{\mathrm{TM}}$, and HEBP as a final rinse on the microhardness of root dentin. J Conserv Dent 2012;15:170-3.

11. Schwartz RS. Adhesive dentistry and endodontics. Part 2: bonding in the root canal system-the promise and the problems: a review. J Endod 2006;32: 1125-34.

12. Cunningham WT, Balekjian AY. Effect of temperature on collagen-dissolving ability of sodium hypochlorite endodontic irrigant. Oral Surg Oral Med Oral Pathol 1980;49:175-7.

13. Dychdala GR. Chlorine and chlorine compounds.
In: Block SS, ed. Disinfection, sterilization and preservation. Philadelphia; Lea \& Febiger; 1991. p. 131-51.

14. Siqueira JF Jr, Batista MM, Fraga RC, de Uzeda M. Antibacterial effects of endodontic irrigants on black-pigmented gram-negative anaerobes and facultative bacteria. J Endod 1998;24:414-6.

15. Heling I, Chandler NP. Antimicrobial effect of irrigant combinations within dentinal tubules. Int Endod J 1998;31:8-14.

16. Moorer WR, Wesselink PR. Factors promoting the tissue dissolving capability of sodium hypochlorite. Int Endo J 1982;15:187-96.

17. Zapata RO, Bramante CM, de Moraes IG, Bernardineli N, Gasparoto TH, Graeff MS, Campanelli AP, Garcia RB. Confocal laser scanning microscopy is appropriate to detect viability of Enterococcus faecalis in infected dentin. J Endod 2008;34:1198201. 


\section{근관세정제와 상호작용시 Hydroxyethylidene bisphosphonate (HEBP)의 조직용해능력, 항균효과에 대한 연구}

\section{김난아, 김윤건, 김미연, 송병철, 김선호, 김정희*}

한국보훈복지공단 중앙보훈병원 치과보존과

목적: 근관 세정제로서 Hydroxyethylidene bisphosphonate (HEBP)가 다른 근관 세정제인 Sodium hypochlorite $(\mathrm{NaO}-$ $\mathrm{Cl})$, Etylenediaminetetraacetic acid (EDTA) 상호 작용 시 조직용해 능력, 항균효과와 온도에 따른 조직 용해 능력의 변 화에 대해 알아보았다.

연구 재료 및 방법: 소의 근육으로 제작된 동일한 단면적 $(2 \times 2 \times 2 \mathrm{~mm})$ 을 가진 80 개의 시편을 8 개의 그룹 $(\mathrm{n}=10)$ 으로 임의로 나누었다. 초기 무게 측정 후 각각의 제조된 근관 세정제에 넣어 5 분, 10 분, 15 분 후 무게를 측정하여 무게변화율 을 구하였다. 항균 효과 조사를 위해 Enterococcus faecalis를 접종한 agar diffusion test를 시행하였다.

결과: 조직 용해 능력은 $\mathrm{NaOCl}$ group $(\mathrm{G} 4,5)$ 이 가장 뛰어났으며, $\mathrm{NaOCl}$ 과 $\mathrm{HEBP}$ 의 혼합물 $(\mathrm{G} 7,8)$ 이 다음으로 나타 났다. 또한 가열된 $\left(40^{\circ} \mathrm{C}\right) \mathrm{NaOCl}$ 과 $\mathrm{NaOCl} / \mathrm{HEBP}$ 의 혼합물의 경우 실온 $\left(25^{\circ} \mathrm{C}\right)$ 보다 우수한 조직용해 능력이 나타났다. 항균 효과의 경우 $\mathrm{EDTA}>\mathrm{EDTA}+1 \% \mathrm{NaOCl}>1 \% \mathrm{NaOCl} \geq 1 \% \mathrm{NaOCl}+\mathrm{HEBP}$ 순으로 나타났다.

결론: $\mathrm{HEBP}$ 는 $\mathrm{NaOCl}$ 의 항균 효과를 방해하지 않으며, 조직 용해 능력에도 기존의 킬레이팅 제재에 비해 적은 영향을 미친다. 가열된 $\mathrm{NaOCl}, \mathrm{NaOCl}$ 과 $\mathrm{HEBP}$ 의 혼합재제는 실온과 비교 시에 효율적으로 조직을 용해할 수 있다.

(구강회복응용과학지 2017;33(2):106-13)

주요어: HEBP (Hydroxyethylidene bisphosphonate); 근관 세정제; 약한 킬레이트 제재; 조직용해능력; 항균 효과 